\title{
Notes
}

\section{Municipal Liability for Police Misconduct: Must Victims Now Prove Intent?}

\author{
Ruth Friedman
}

On September 28, 1981, armed officers of the Springfield, Massachusetts police department embarked on a high-speed chase of Clinton Thurston, a suspect in an assault case. One officer drew his gun with the intent to kill. Another fired several shots into the driver's seat. When the car stopped, a third struck Thurston on the head with his flashlight. The officers then dragged the suspect, unconscious, from his car, and handcuffed him. Thurston died a short time later from a bullet wound to his brain. ${ }^{1}$

Adolph Lyons was stopped by two officers of the Los Angeles Police Department on October 6, 1976, at 2:00 a.m. because one of his taillights was burned out. The policemen greeted the 24-year old black man with drawn revolvers. He was told to face his car, spread his legs, and clasp his hands on top of his head. Although Lyons complied, one of the officers grabbed his hands, slammed them onto his head, handcuffed him, and choked him until he blacked out. When Lyons regained consciousness, he was lying on the ground, spitting up blood and dirt. He had urinated and defecated. He was issued a traffic citation and released. ${ }^{2}$

1. Kibbe v. City of Springfield, 777 F.2d 801, 802-03, 807 (1st Cir. 1985), cert. granted, 475 U.S. 1064 (1986), cert. dismissed, 107 S. Ct. 1114 (1987).

2. City of Los Angeles v. Lyons, 461 U.S. 95, 114-15 (1983) (Marshall, J., dissenting). 
Believing that the police had violated their constitutional rights, Thurston's heirs and Adolph Lyons sought redress under 42 U.S.C. $§ 1983,{ }^{3}$ which provides for civil rights suits against government officials. These plaintiffs sued not only the individuals who fired the shots or used the chokehold but also the police departments of Springfield and Los Angeles, which they contended had failed to train and supervise the officers properly. ${ }^{4}$ Like many other victims of police abuse, they sought substantial compensation $^{6}$ and systemwide change ${ }^{6}$ by holding the city accountable for the injurious consequences of its inaction.

Yet the ability of plaintiffs to obtain such relief may now be in jeopardy. When the Supreme Court opened the door to institutional litigation under section $1983,{ }^{7}$ it held that a city government ${ }^{8}$ could be subject to liability whenever an official "policy or custom" caused a constitutional tort. ${ }^{9}$ While declining to elaborate fully on its test, ${ }^{10}$ the Court noted that

3. "Every person who, under color of any statute, ordinance, regulation, custom, or usage, of any State or Territory or the District of Columbia, subjects, or causes to be subjected, any citizen of the United States or other person within the jurisdiction thereof to the deprivation of any rights, privileges, or immunities secured by the Constitution and laws, shall be liable to the party injured in an action at law, suit in equity, or other proper proceeding for redress." 42 U.S.C. $\S 1983$ (1982).

4. Lois Thurston Kibbe maintained that the department's failure to train its officers in the apprehension of fleeing drivers led to Thurston's death. Kibbe v. City of Springfield, 777 F.2d 801, 803-04 (1st Cir. 1985), cert. granted, 475 U.S. 1064 (1986), cert. dismissed, 107 S. Ct. 1114 (1987). Lyons objected to the city's toleration of the use of chokeholds against unresisting suspects. City of Los Angeles v. Lyons, 461 U.S. 95, 116, 120-21 (1983) (Marshall, J., dissenting).

5. Actions against individual officers may fail to provide relief altogether, since the police are entitled to a qualified, "good faith" immunity and because those who are not indemnified by the municipality may have little to offer in the way of compensatory damages. See P. SCHUCK, SuING Government 85-87, 90 (1983); Project, Suing the Police in Federal Court, 88 Yal.E L.J. 781 (1979).

6. The administratix of Thurston's estate, Lois Thurston Kibbe, sought money damages from the city of Springfield. Lyons prayed for financial and injunctive relief in his suit against the Los Angeles Police Department. Court-enforced injunctions are expected to produce changes in municipal practice; the payment of large damage awards may also prod municipalities into instituting reforms.

7. Monell v. Department of Social Services, 436 U.S. 658 (1978).

8. Although a municipality is considered a "person" for purposes of $\S 1983$, it can, of course, act only through its officials. Accordingly, Monell and subsequent cases have affirmed that municipal liability is triggered by the tortious acts of high-ranking government employees. In police misconduct litigation, policymaking authorities generally include not only elected representatives but also the leading officials of the law enforcement agency. See, e.g., Pembaur v. City of Cincinnati, 475 U.S. 469, $482-84$ (1986); see also City of St. Louis v. Praprotnik, No. 86-772 (U.S. Mar. 2, 1988) (LEXIS, Genfed library, U.S. file) (who may be considered "final decisionmaking authority" for purposes of $\S$ 1983 municipal liability is a question of state and local law).

9. Monell, 436 U.S. at 694 . The Court created the "policy or custom" test in an effort to distinguish cognizable claims from those brought under the theory of respondeat superior. Monell held that the mere existence of an employer-employee relationship would not trigger municipal liability under $\S$ 1983. Id. at 691.

The Court's rejection of respondeat superior liability is difficult to defend in light of both the statute's legislative history and the problems that arise in deciding under what circumstances municipal liability may attach. The Court based its decision on the Forty-second Congress' rejection of the Sherman Amendment, which would have imposed liability on local governments for the unconstitutional acts of private citizens, without regard to whether the city had attempted to prevent the violations. While the Court took note of the difference between "the wrongs of a few private citizens" and the torts of a municipality's employees, it premised its holding on the failure of the Reconstruction Congress to impose vicarious liability in the one instance in which it was debated. Id. at $693 \mathrm{n} .57$.

This rationale for rejecting respondeat superior has been roundly criticized by one Justice and by 
a "policy" need not be formal or written to be actionable, ${ }^{11}$ and that the statute should be construed so as to provide a broad remedy. ${ }^{12}$ But recent pronouncements of the Court offer a conception of the policy or custom test $^{13}$ that would limit municipal liability for omission to only the most

numerous legal scholars. Justice Stevens, who deemed this aspect of Monell "merely advisory," continues to assert that allowing respondeat would be the correct interpretation. Id. at 714 (Stevens, J., concurring); see also City of Oklahoma City v. Tuttle, 471 U.S. 808, 834-44 (1985) (Stevens, J., dissenting). For scholarly criticism, see Schnapper, Civil Rights Litigation after Monell, 79 CoLuM. L. REv. 213, 215 n.15 (1979); Whitman, Government Responsibility for Constitutional Torts, 85 U. Mich. L. Rev. 225, 236 \& n.43 (1986); Note, Section 1983 Municipal Liability, and the Doctrine of Respondeat Superior, 46 U. CHr. L. Rev. 935, 940-47 (1979).

Because the employer is generally in the best position to deter harm and implement reform, rejection of the doctrine is vulnerable to further attack on public policy grounds. See P. Schuck, supra note 5, at 100-05, 111-12, 119-21 (1983). However, as the Court has repeatedly affirmed its commitment to the "policy or custom" approach, this Note will not attempt to argue for adoption of respondeat superior liability under $\S 1983$. See Pembaur, 475 U.S. at 478-79; Tuttle, 471 U.S. at 818.

10. Monell, 436 U.S. at 695.

11. Id. at 691 \& n.56.

Rarely will victims of police brutality be able to point to a specific municipal regulation authorizing police misconduct. Instead, plaintiffs assert departmental responsibility by identifying practices within the department that allowed the misconduct to occur. The two most common claims are that the city failed to train or prepare its officers properly ("inadequate training") or that it tacitly authorized brutality by failing to punish previous misconduct ("negligent supervision" or "failure to control"). Related allegations include negligent hiring (for example, admitting to the force an applicant with cognizable violent propensities) or retention. For a discussion of the various theories of supervisory liability for police misconduct, see Note, Municipal Liability for Requiring Unfit Police Officers to Carry Guns, 11 Fordham URB. L. J. 1001, 1012-16 (1983); Note, Monell and Owen in the Police Injury Context: Municipal Liability under Section 1983 Without Supervisorial Fault, 16 U.S.F. L. REv. 517, 521 (1982).

12. Monell, 436 U.S. at 685.

While the Monell Court did not comment directly on whether failures or omissions could constitute policy or custom, its discussion of one leading police misconduct case, Rizzo v. Goode, 423 U.S. 362 (1976), is instructive. In Rizzo, the Court denied relief on the theory that plaintiffs had not shown an "affirmative link" between municipal conduct and the alleged abuse. Id. at 371 . Monell limited the Rizzo decision to the proposition that "the mere right to control without any control or direction having been exercised and without any failure to supervise is not enough to support $\$ 1983$ liability." Monell, 436 U.S. at 694 n.58 (emphasis added). The implication here is that had plaintiffs proved a failure to supervise, their claim against the City of Philadelphia would have been colorable.

In the ten years since Monell was decided, most courts entertaining suits against police departments have considered "inadequate training" or "failure to supervise"- the theories of liability on which most plaintiffs base their municipal claims-cognizable under the policy or custom test. See, e.g., Depew v. City of St. Marys, 787 F.2d 1496 (11th Cir. 1986) (plaintiffs claim that city failed to respond to previous complaints of beatings by police actionable under $\$ 1983$ ); Herrera v. Valentine, 653 F.2d 1220 (8th Gir. 1981) (continuing failure to remedy known unconstitutional conduct of officers is informal policy or custom amenable to suit under $\S 1983$ ); Hardeman v. Clark, 593 F. Supp. 1285 (D.D.C. 1984) (allegation that improper training in use of blackjack responsible for plaintiff's injury found cognizable). See also Eiland v. Hardesty, 564 F. Supp. 930 (N.D. Ill. 1982) (allegations that improper screening, hiring, training, supervising, controlling, and disciplining encouraged misconduct and proximately caused plaintiff's injuries stated claim); Starstead v. City of Superior, 533 F. Supp. 1365 (W.D. Wis. 1982) (plaintiff need not point to specific municipal rule where "policy" could be inferred from systematic pattern of misuse of police dogs).

However, judicial treatment of the standard of proof necessary for a plaintiff to prevail in an inadequate training case has varied. Some courts have held "negligence" or "gross negligence" in training actionable. See, e.g., Berquist v. County of Cochise, 806 F.2d 1364 (9th Gir. 1986); McKinnon v. City of Berwyn, 750 F.2d 1383 (7th Cir. 1984). Others have required a higher standard, such as traininis that "inevitably" leads to misconduct or is "consciously" or "deliberately indifferent" to plaintiff"s rights. See, e.g., Patzner v. Burkett, 779 F.2d 1363 ( 8 th Cir. 1985); Languirand v. Hayden, 717 F.2d 220 (5th Cir. 1983), cert. denied, 467 U.S. 1215 (1984). See infra notes 17 and 25 and accompanying text.

13. Courts and legal scholars have debated whether allegations of inadequate training and negli- 
flagrant misconduct. These opinions suggest that a showing of explicit authorization or intent ${ }^{14}$ may be necessary before a city can be found liable for violating constitutional rights.

This Note argues that this emerging trend, not yet adopted by a majority of the Court, ${ }^{15}$ should be rejected. Section I exposes the intent requirement implicit in three recent opinions by members of the Court. Section II explores the flaws in this approach, showing that it both betrays fundamental misconceptions about how cities cause harm and contravenes the legislative purpose of the civil rights statute. Section III offers a proposal for judicial consideration of municipal inaction claims that is based on objective assessments of government responsibility and is consistent with the purposes of section 1983 and the Court's own "policy or custom" test.

\section{Emerging Proof-of-Intent Requirement}

The Supreme Court has never directly addressed the issue of when a police department's failure to act may trigger section 1983 liability. But in three of the major police misconduct cases to come to the Gourt in recent years, several of the Justices have indicated that only intentional omissions or direct authorization should subject a municipality to suit under Monell.

\section{A. City of Springfield v. Kibbe}

In a detailed dissent from dismissal of certiorari in City of Springfield v. Kibbe ${ }^{16}$ four Justices maintained that plaintiffs should prevail on a theory of inadequate police training only when they can offer proof of municipal intent. Ratifying the approach taken by a number of lower

gent supervision should be considered official "policy" or "custom." See Oliver, Municipal Liability for Police Misconduct under 42 U.S.C. $\$ 1983$ after City of Oklahoma City v. Tuttle, 64 WaSH. U.L.Q. 151, 180-85 (1986) (inadequate training presupposes "policy" choices about training programs and does not require pattern or "custom" evidence to establish); see also Comment, Liability of a Municipality for Acts Committed by Its Police Officers: Inadequate Training Demands Strict Custom or Policy Test, 53 U. CIN. L. REv. 524 (1984). Some courts have confused the two concepts by requiring both a "policy" of inadequate training and a "custom" of abuse under that policy before liability can be imposed. See Wellington v. Daniels, 717 F.2d 932, 936 (4th Cir. 1983); Languirand v. Hayden, 717 F.2d 220, 227-28 (5th Cir. 1983), cert. denied, 467 U.S. 1215 (1984). Plaintiffs, meanwhile, generally use both terms in their pleadings ("a policy or custom of inadequate training") to avoid dismissal. As the analytic distinctions between the two are not critical to this discussion, they will not be considered here.

14. See infra notes $16-44$ and accompanying text.

The term "intent" is used by courts and commentators to explain several related concepts and is not easily defined. See W. Prosser \& W. Keeton, The LAW of Torts § 8, at 33 (1984). The search for intent usually focuses directly on the actor's state of mind. Id. $\$ 8$, at 34 ; Daniels v. Williams, 474 U.S. 327, 329-30 (1986) (claim of discriminatory purpose necessitates state-of-mind inquiry). Intent can be said to include not only a desire to bring about certain consequences but also a belief or knowledge that given consequences are substantially certain to result from what one does. W. PRosSER \& W. KEETON $\$ 8$, at 34 .

15. See infra notes 16-35 and accompanying text. The elevation of Judge Anthony Kennedy to the Court renders future treatment of this issue particularly uncertain. Judge Kennedy's few opinions on municipal liability shed little light on how he will analyze $\S 1983$ claims premised on inaction.

16. 107 S. Ct. 1114 (1987). See supra notes $1-6$ and accompanying text. 
courts, ${ }^{17}$ these dissenters would preclude relief unless a plaintiff could show "deliberate indifference"18 or "recklessness"18 by officials in choosing the training procedures in question.

After challenging the majority's view on the posture of the case, ${ }^{20}$ Justice O'Connor's dissent ${ }^{21}$ proceeded to reject grossly negligent training as a "policy" embraced by Monell. The dissent based its determination on the importance of distinguishing actionable claims against municipalities from those alleging vicarious liability. ${ }^{22}$ Characterizing the causal link between inadequate training and the use of excessive force as "inherently tenuous," speculative, and conjectural, ${ }^{23}$ the dissenters argued that only a "cognitive component" could establish the proof of causation required by Monell. ${ }^{24}$ In their view, no wrong could be ascribed to municipal decisionmakers who had not acted recklessly or deliberately.

The vigorous Kibbe dissent is critical: Although it constitutes only a minority view at present, it is the first time a significant segment of the Court has called openly for an intent-based liability test for municipal

17. Id. at 1121 (O'Connor, J., dissenting). See infra note 25.

18. Id. The Supreme Court understands the "deliberate indifference" standard to require an inquiry into the state of mind of the actor. See Daniels v. Williams, 474 U.S. 327, 329-30 (1986); see also supra note 14.

This test originated in Estelle v. Gamble, 429 U.S. 97 (1976) (allegations of medical malpractice in prison). The Estelle Court held that a prisoner "must allege acts or omissions sufficiently harmful to evidence deliberate indifference to serious medical needs" in order to claim a violation of the Eighth Amendment. Id. at 106. For a discussion of why that standard should not be borrowed by courts entertaining municipal liability claims, see infra notes 45-72 and accompanying text; see also Oliver, supra note 13, at 164-65; Note, Monell and Owen in the Police Injury Context, supra note 11, at 525.

19. Kibbe, 107 S. Ct. at 1121 (O'Connor, J., dissenting). The Court also views "recklessness" as necessitating a state-of-mind inquiry. See Davidson v. Cannon, 474 U.S. 344, 356-58 (1986) (Blackmun, J., dissenting).

20. Plaintiff's claim that negligent police training caused the shooting of her decedent prevailed at trial and was upheld by the First Circuit. The City of Springfield then appealed to the Supreme Court. Kibbe certified the question of whether inadequate training could be considered a "policy" actionable under Monell and, if so, whether simple or "gross" negligence could suffice to establish liability. However, the Court dismissed the case on the ground that the municipal defendant had not preserved the issue by objecting during trial to the standard imposed. Kibbe, $107 \mathrm{~S}$. Ct. at 1115-16. $\Lambda$ per curiam opinion held that due to the "close interrelationship" between the viability of the theory and the standard of proof, neither question could be considered. Id. The dissent nevertheless contended that the Court should have addressed the issue because it had been decided by the court of appeals. Id. at 1118-19 (O'Connor, J., dissenting).

21. The dissent was joined by Justices Powell and White and Chief Justice Rehnquist.

22. "Given the importance, under $\S 1983$, of distinguishing between direct and vicarious liability, the Court repeatedly has stressed the need to find a direct causal connection between municipal conduct and the constitutional deprivation. . . . Negligence in training alone is not sufficient to satisfy the causation requirement of $\S 1983 . " I d$. at 1120,1121 (O'Connor, J., dissenting).

23. Id. at 1121,1122 . The dissenters distinguished Kibbe's "tenuous" allegation from a presumably colorable claim that the city "authorized" the use of deadly force in apprehending fleeing felons. Id. at 1120 (O'Connor, J., dissenting).

24. Id. at 1121 . 
omission. ${ }^{25}$ Lower courts have already cited the dissent in their treatment of inaction claims. ${ }^{26}$

\section{B. City of Oklahoma City v. Tuttle}

The standard announced in the Kibbe dissent was foreshadowed by strong dicta in City of Oklahoma City $v$. Tuttle, ${ }^{27}$ a 1985 police brutality case. Rose Marie Tuttle, the widow of a man shot by a city policeman, sued the Oklahoma City government for permitting the use of excessive force through improper training and supervision. The Court reviewed the case because an instruction had allowed the Tuttle jury to infer the existence of a policy from this officer's act alone, absent any independent evidence on municipal behavior. ${ }^{28}$ Seven Justices concurred in the decision to overturn the jury award due to the erroneous instruction.

But Justice Rehnquist's plurality opinion ${ }^{28}$ went beyond the narrow holding to challenge the concept of omission-as-policy. Deeming inadequate training a "nebulous" allegation not easily amenable to the causation inquiry, ${ }^{30}$ the plurality would require a plaintiff to submit proof that "policymakers deliberately chose a training program which would prove

25. A number of lower courts were already employing a proof-of-intent standard in the inadequate training context. See, e.g., Patzner v. Burkett, 779 F.2d 1363, 1367 (8th Cir. 1985) (for municipality to be held liable, training must be conducted in so grossly negligent a manner that police misconduct inevitably occurs); Hays v. Jefferson County, 668 F.2d 869, 873-74 (6th Cir.), cert. denied, 459 U.S. 833 (1982) (court denied claim for lack of proof that city had "a culpable state of mind-that the action or failure to act was to some degree deliberate rather than inadvertent"); see also Fecteau v. Unknown Officers of Clinton, 596 F. Supp. 580, 583 (E.D. Mich. 1984) (failure to train must be so grossly inadequate that misconduct is certain to result); Sager v. City of Woodland Park, 543 F. Supp. 282, 289 n.5 (D. Colo. 1982) (training so negligent that future harm almost inevitable).

Several courts utilize the "deliberate indifference" phrase preferred by the Kibbe dissenters. See, e.g., Wellington v. Daniels, 717 F.2d 932, 936 (4th Cir. 1983); Turpin v. Mailet, 619 F.2d 196, 202 (2d. Cir.), cert. denied sub nom Turpin v. City of West Haven, 449 U.S. 1016 (1980); Caiani v. Town of Walpole, 624 F.Supp. 311, 314 n.5 (D. Mass. 1985); Spell v. McDaniel, 591 F. Supp. 1090,1110 (E.D.N.C. 1984); Leite v. City of Providence, 463 F. Supp. 585, 590 (D.R.I. 1978). But see Edmonds v. Dillin, 485 F. Supp. 722, 727 (N.D. Ohio 1980) ("Because this court believes that the 'deliberate indifference' standard of Estelle v. Gamble should be confined to Eighth Amendment applications, this court declines to adopt it in fashioning a Monell standard applicable to a police training case."). See also infra notes $45-72$ and accompanying text.

Finally, some judges have used the terms "gross negligence" and "deliberate indifference" interchangeably. see, e.g., Clayton v. City of New York, 596 F. Supp. 355 (S.D.N.Y. 1984) (gross negligence or deliberate indifference required). The Kibbe dissent differentiated between the two in rejecting the former as a legitimate policy under Monell.

Given the wide disagreement among the courts as to the appropriate standard to apply (see supra note 12 ), it is highly likely that the Court will again face the question ultimately dismissed in Kibbe.

26. See, e.g., Tompkins v. Frost, 655 F. Supp. 468, 471 (E.D. Mich. 1987); see also Lopez v. Houston Indep. School Dist., 817 F.2d 351, 354 (5th Cir. 1987).

27. 471 U.S. 808 (1985).

28. Tuttle had offered independent proof of inadequate training, relying largely on expert evaluations of Oklahoma City Police Department programs. Id. at 811-12. The instruction, however, allowed the jury to find the department liable even if it did not deem the plaintiff's evidence credible-that is, even without proof that the acts or omissions of a policymaker were tortious.

29. Chief Justice Burger and Justices White and O'Connor joined this opinion.

30. Id. at $822-23$. 
inadequate." Thi These Justices expressed doubt as to whether gross negligence in training could ever give rise to liability absent a "more conscious decision"32 by a municipal authority.

Like the cognitive component sought by the Kibbe dissent, the search for a "conscious decision" would force plaintiffs to determine the consequences supervisors envisioned when they chose to train or discipline in a particular manner. ${ }^{33}$ Under the plurality approach, police officials could escape liability where their omissions permitted misconduct but where they themselves had not foreseen the result. ${ }^{34}$ Despite the limited nature of Tuttle's formal holding, courts have interpreted the plurality opinion as requiring a state-of-mind inquiry where inadequate training is alleged. ${ }^{\mathbf{3 5}}$

\section{City of Los Angeles v. Lyons}

When police brutality victims have sought equitable relief, a majority of the Court has rejected municipal omission as a basis for remedial action.

31. Id. at 823 . These Justices would require proof that "the inadequacies resulted from conscious choice." Id. They expressed the fear that without such proof plaintiffs could go so far as to contend that the "policy" of establishing a police force caused their injuries.

32. Id. at 824 n.7. The opinion distinguished between policies that are themselves unconstitutional, such as the regulation challenged in Monell, and those that are not, such as grossly inadequate training, implying that the latter might not fit within the "policy or custom" framework. Id. This distinction, unsupported by the language of Monell, has been endorsed in dicta in later cases. See, e.g., City of Springfield v. Kibbe, 107 S. Ct. 1114, 1121-22 (1987) (O'Connor, J., dissenting) (policies not facially unconstitutional require more evidence to establish); City of St. Louis v. Praprotnik, No. 86772 (U.S. Mar. 2 1988) (LEXIS, Genfed library, U.S. file) (plaintiff must prove existence of unconstitutional policy to recover). But see id. (Brennan, J,, concurring) (Kibbe and Tuttle reserved question of whether policy not unconstitutional on its face can cause constitutional deprivation; despite plurality language suggesting otherwise, Praprotnik did not decide issue).

33. By requiring proof that police officials knew that their programs were deficient when they chose them, the Tuttle plurality mandated a showing of municipal intent. See supra note 14. Some trial judges and litigants have explicitly interpreted the opinion as requiring proof of intent. See infra note 35 .

34. Commentators have criticized the Tuttle opinion for conflating Monell's policy and causation inquiries and for imposing an unacceptable burden of proof on the police misconduct plaintiff. See Oliver, supra note 13, at 177-79; Comment, Municipal Liability under Section 1983: Rethinking "Policy or Custom" after City of Oklahoma City v. Tuttle, 71 Iowa L. Rev. 1209, 1222-29 (1986); see also Mead, 42 U.S.C. \& 1983 Municipal Liability: The Monell Sketch Becomes a Distorted Picture, 65 N.C.L. Rev. 517, 555-56 (1987) (if Court concludes that policies not in themselves unconstitutional fail to meet Monell requirement, inadequate training claims will be eradicated).

35. See, e.g., Carter v. District of Columbia, 795 F.2d 116 (D.C. Cir. 1986); Kelson v. Gity of Springfield, 767 F.2d 651, 656 (9th Cir. 1985); Kime v. Wise, 634 F. Supp. 514, 517 (N.D. Ohio 1985); Martin v. City of New York, 627 F. Supp. 892 (E.D.N.Y. 1985); Mariani v. City of Pittsburgh, 624 F. Supp. 506 (W.D. Pa. 1985); Boren v. City of Colorado Springs, 624 F. Supp. 474, 480-81 (D.Colo. 1985).

Municipalities challenging the inadequacy claims against them have also cited Tuttle as a bar to such allegations. See, e.g., Fiacco v. City of Rensselaer, 783 F.2d 319, 326 (2d Cir. 1986) (defendant claimed municipal policy must be unconstitutional or intentionally pursued to create liability); see also Western World Ins. Co. v. Hartford Mutual Ins. Co., 784 F.2d 558, 563 (4th Cir. 1986) (insurance company seeking to avoid paying judgment interpreted Tuttle to hold supervisory officials liable only for intentional conduct).

Some lower courts, however, have rejected Tuttle's burden of proof or limited that case to its facts. See, e.g., Wierstak v. Heffernan, 789 F.2d 968 (1st Cir. 1986) (liability upheld for failure to train where arrestee was beaten with revolver since plaintiff submitted direct testimony on both training and institutional failure to respond and expert presented evidence as to proximate causation). 
In City of Los Angeles v. Lyons, ${ }^{36}$ plaintiff sued to enjoin the Los Angeles Police Department from using a dangerous, often deadly "chokehold" on nonviolent suspects. After requiring that Lyons establish standing separately for his equitable and legal claims, ${ }^{37}$ the Court demanded proof that he would again be subject to the tactic before injunctive relief would even be considered. But because Lyons could not show that the department affirmatively ordered use of the chokehold where no resistance was offered (or that officers used the device in every citizen encounter), the Court found the threat of future injury a matter of "speculation" and "conjecture" ${ }^{138}$ and denied standing for the equitable claim..$^{39}$

While the majority maintained that Lyons could still pursue a damages remedy, ${ }^{10}$ its search for affirmative municipal authorization rendered the legal claim equally problematic. Looking only to official regulation and instruction, the Court averred that it was an "unbelievable assertion that the City either orders or authorizes application of the chokeholds where there is no resistance or other provocation."'11 The Justices declined to entertain plaintiff's actual claim that the city countenanced misuse of the tactic by failing to take corrective action. ${ }^{42}$ They implicitly refused to rec-

36. 461 U.S. 95 (1982). See supra notes 2-6 and accompanying text.

37. The bifurcation of the standing inquiry has been widely criticized as an improvident innovation that undermines the purposes of $\S 1983$. See Nahmod, Damages and Injunctive Relief under Section 1983, 16 Urb. LAw. 201, 213-16 (1984); Comment, City of Los Angeles v. Lyons, 30 N.Y.L. ScH. L. Rev. 165, 190-91 (1985); Note, Standing and Injunctions: The Demise of Public Law Litigation and Other Effects of Lyons, 25 B.C.L. Rev. 765, 794-97 (1984).

38. Lyons, 461 U.S. at 108.

39. Lower courts have already denied injunctions to alleged victims of police abuse based on the Lyons analysis. See Comment, supra note 37, at 186 n.138; Note, supra note 37, at 767-68 \& n.26; see also Schmidtberger, No Holds Barred in City of Los Angeles v. Lyons: Standing to Seek Injunctions in Federal Court Against Municipalities, 15 CoLum. Hum. RTs. L. Rev. 183, 197-98 (1984) (Lyons may foreclose injunctions in all but most obvious and ongoing cases of constitutional violations; Court seems to be allowing injunctions only with proof of deliberate municipal wrongdoing).

40. Although it discussed the action for damages, the Court actually decided only the equitable claim. In addition to its demand that plaintiff prove certainty of future harm, the Court's ruling on the injunction was guided by the view that the judiciary should exercise restraint when asked to enjoin the operations of local agencies. Lyons, 461 U.S. at 112.

41. Id. at $106 \mathrm{n.7}$ (emphasis added).

42. Yet the dissent understood-and the district court established as a finding of fact-that Lyons was claiming that the city's toleration of such use of the device rendered it liable for the injuries he suffered. Id. at 121-22 (Marshall, J., dissenting). For similar treatment of an analogous claim in equity, see Rizzo v. Goode, 423 U.S. 362, 373-76 (1975) (distinguishing between an intentional plan undertaken by the city, which might give rise to liability, and a failure to act, which did not); $i d$. at 383-86 (Blackmun, J., dissenting) (majority rejected district court's factual determination that departmental failure to act was cause of plaintiffs' injuries in that it rendered brutality likely to recur). 
ognize that conduct short of direct authorization ${ }^{43}$ could constitute "policy" actionable under Monell.4

\section{Requiring Proof of Intent or Authorization Is INAPPROPRIATE}

If the Court adopts the standard articulated in the Kibbe dissent (and implicit in Tuttle and Lyons) police administrators will be subject to liability only for deliberate omissions or explicit authorization of misconduct. But when municipal responsibility is alleged under section 1983, the demand for proof of intent is wholly inappropriate.

Supreme Court jurisprudence has continually reaffirmed that section 1983 imposes no blanket state-of-mind inquiry on all litigants. ${ }^{45}$ When the Court has required proof of intent under the statute, it has done so in order to establish violations of specific constitutional guarantees, such as the Eighth Amendment's ban on cruel and unusual punishment ${ }^{46}$ or the Fourteenth Amendment's equal protection ${ }^{47}$ and due process ${ }^{48}$ clauses. In these cases, the constitutional harm is defined in terms of the defendant's

43. Sometimes the Court's treatment of municipal claims evinces a seemingly inadvertent focus on authorization. Such was probably the case in Justice Brennan's opinion in Pembaur v. City of Cincinnati, 475 U.S. 469 (1986) (county official's single order to subordinates to violate petitioner's Fourth Amendment rights constituted "policy" within the meaning of Monell). While the case has been read as expanding the scope of municipal liability, the plurality in Pembaur adopted language from Tuttle that could jeopardize a remedy for some $\S 1983$ plaintiffs. After holding for the plaintiff-petitioner, the Court set out the circumstances under which a city might be held liable for the acts of its highranking officials. Justice Brennan stated that "municipal liability under $\$ 1983$ attaches where-and only where-a deliberate choice to follow a course of action is made from among various alternatives." Id. at 483 .

While this language was probably not intended to restrict claims against municipalities, lower courts have read the opinion to require an inquiry into the state of mind of a policymaker where failures to act form the basis of a plaintiff's claim. See, e.g., Strandell v. Jackson City, 648 F. Supp. 126, 130 (S.D. Ill. 1986) (Tuttle and Pembaur indicate need for deliberation and conscious action for municipal liability to be imposed); Bartalone v. County of Berrien, 643 F. Supp. 574, 577-78 (W.D. Mich. 1986) (Pembaur holding on deliberation reinforces standard of "inevitability" of misconduct); City of Miami v. Harris, 490 So. 2d 69, 75 (Fla. Dist. Ct. App. 1986) (misconduct case remanded in light of Pembaur for proof that inadequate training was result of deliberate choice on part of city).

44. The significance of the Kibbe, Tuttle, and Lyons opinions is underscored by the Court's willingness to restrict state or municipal liability in other contexts. Often citing federalism concerns, the Court has repeatedly rejected constitutional claims against local governments. See, e.g., Hudson v. Palmer, 468 U.S. 517 (1984) (state post-deprivation remedy sufficient where prisoner suffered loss of property); Pennhurst State School and Hosp. v. Halderman, 465 U.S. 89 (1984) (protections of Eleventh Amendment extended to preclude municipal damage awards that might ultimately be drawn from state coffers); Ingraham v. Wright, 430 U.S. 651 (1977) (Court declined to adjudicate even though state remedy unequal to that available under $\$ 1983$ ). See generally Blackmun, Section 1983 and Federal Protection of Individual Rights-Will the Statute Remain Alive or Fade Away?, 60 N.Y.U. L. REv. 1 (1985) (criticizing recent $\S 1983$ case law for wrongly denying plaintiffs access to federal forum).

45. See, e.g., Daniels v. Williams, 474 U.S. 327, 329-30 (1986).

46. Estelle v. Gamble, 429 U.S. 97 (1976) (plaintiff must allege "deliberate indifference" to medical needs to state cognizable Eighth Amendment claim).

47. Arlington Heights v. Metropolitan Hous. Dev. Corp., 429 U.S. 252 (1977) (proof of discriminatory purpose required).

48. Daniels v. Williams, 474 U.S. 327 (1986) (negligence insufficient to implicate due process clause). 
state of mind; plaintiffs who cannot show recklessness or deliberation will fail to prove a deprivation of their civil rights.

But when the issue is municipal liability, the court is not being asked to determine whether an injury is of constitutional dimension: Any citizen who seeks to sue the city must first establish that his rights were violated. ${ }^{90}$ The court must instead decide whether the city can be held responsible for that injury. This question turns not on constitutional interpretation but on construction of the Monell test and the civil rights statute from which that test is derived.

\section{A. Inadequate Training Satisfies Monell's Causation Inquiry}

According to Monell, a police misconduct victim must prove that the city agency had a "policy" that "caused" her injuries. ${ }^{\text {so }}$ The Kibbe dissenters and the Tuttle plurality doubted that these plaintiffs could satisfy the second prong of the test: They believed that a policy of improper training or supervision was too tenuously linked to the use of excessive force to meet the causation requirement absent an inquiry into a supervisor's state of mind. ${ }^{\text {s1 }}$

This characterization of the issue, however, reveals a fundamental misunderstanding of how law enforcement authorities violate citizens' rights.

49. See, e.g., City of Oklahoma City v. Tuttle, 471 U.S. 808, 816-17 (1985). For example, one who claims that he was beaten by the police must prove that the beating was constitutionally prohibited before he can proceed in a $\$ 1983$ suit against the municipality. In some cases, the use of excessive force by a law enforcement agent may be considered an unlawful seizure barred by the Fourth Amendment. Tennessee v. Garner, 471 U.S. 1 (1984). In others, courts may determine that only state tort law was violated and that the alleged injuries are not cognizable under $\$ 1983$, or that the amount of force used to effect the arrest was not excessive. Tuttle, 471 U.S. at 817 n.4. The distinct legal standards involved in adjudication of the underlying constitutional claim are beyond the scope of this Note.

Once the plaintiff has prevailed against the officer on the federal claim, he can attempt under Monell's policy or custom test to prove municipal responsibility for his injury.

50. See supra notes 7-12 and accompanying text. See also Tuttle, 471 U.S. at 828-32 (Brennan, $\mathrm{J}$, concurring) (describing how allegations of inadequate training fit within Monell scheme).

51. See supra notes 23-25 and 30-33 and accompanying text. These members of the Court appear to be demanding deliberation, foresight, or affirmative authorization under $\S 1983$ in an attempt to distinguish actionable governmental conduct from respondeat superior liability. See City of Springfield v. Kibbe, 107 S. Ct. 1114, 1120-22 (1987) (O'Connor, J., dissenting); see also Whitman, supra note 9, at 255 (Court is assuming all institutional liability must be vicarious or affirmative); Note, Municipal Liability Under Section 1983: The Failure to Act as Custom or Policy, 29 WAyn L. REv. 1225, 1241 (1983) (courts are equating causation with action). It is also highly likely that the Justices are motivated by concerns unexpressed in these opinions, such as a desire to insulate the federal courts from suits purportedly more appropriate for a state forum, or to preserve local autonomy. See supra note 44; Paul v. Davis, 424 U.S. 693, 701 (1976) (fear of federal courts becoming "font" of tort law claims if plaintiffs injury recognized as due process violation).

While such fears may be understandable, they cannot justify denial of a federal forum to those who can properly prove their claims. Section 1983 entitles a plaintiff who can show that her civil rights were violated and who can satsify the Monell test to litigate her suit in federal court; redefining that test to restrict a particular cause of action is not a defensible method for reducing caseload. Moreover, a finding of liability would not imply severe intrusion into local affairs but would merely affirm that cities cannot conduct their operations in a manner that impermissibly burdens citizens' rights. See infra notes 81-83 and accompanying text. For a discussion of how the Court is straining otherwise sound doctrines in an effort to restrict $\S 1983$ actions, see Blackmun, supra note 44, at 2-3, 21-29. 
The indifference of supervisors-whether or not deliberate ${ }^{\mathbf{3 2}}$-may give police officers reason to believe that they may act without fear of discipline or control or may lead poorly trained officers into confrontations for which they are ill prepared. ${ }^{\mathbf{s}}$ Bureaucratic inertia, poorly conceived structural arrangements, or outdated procedures may also produce constitutional violations regardless of the good intentions of supervisory personnel. ${ }^{54}$ A police department that adopts ineffective disciplinary rules or inadvertently ignores it own regulations ${ }^{\mathrm{s \sigma}}$ may encourage the same unlawful behavior as a department that knowingly implements faulty procedures.

Failure to recognize the link between an administrator's unintended omissions and the use of excessive force by subordinates has led the Justices to ignore powerful indications of causation. ${ }^{58}$ Contrary to the dissent's assertions in Kibbe, the jury could have decided that the city bore primary responsibility for Thurston's death. ${ }^{57}$ The plaintiff in Kibbe presented testimony that officers were given virtually no guidance in ap-

52. Police administrators play a vital role in managing their subordinates. See, e.g., Newman, Suing the Lawbreakers: Proposals to Strengthen the Section 1983 Damage Remedy for Law Enforcers' Misconduct, 87 YALE L.J. 447, 457 (1978); P. ScHuck, supra note 5. Where police officials offer training without considering its adverse effects, or ignore a series of brutal incidents, their omissions may indeed cause harm. See Chapman, Police Policy on the Use of Firearms, in Readings on Police Use of Deadly Force 224, 234 (J. Fyfe ed. 1982); Rittenmeyer, Vicarious Liability in Suits Pursuant to 42 U.S.C. 1983: Legal Myth and Reality, 12 J. Police ScI. \& Admin. 260, 265 (1984).

53. See Brown, Use of Deadly Force by Patrol Officers: Training Implications, $12 \mathrm{~J}$. Police Scr. \& ADMIN. 133 (1984); (improved training reduces likelihood of excessive shooting); Davis, $A n A p$ proach to Legal Control of the Police, 52 TEx. L. REv. 703, 723 (1974) (indifference of supervisors critical in perpetuating police misconduct); Meagher, Organizational Integrity: The Role of the Police Executive in the Management Process, 13 J. Police ScI. \& ADMIN. 236, 237 (1985) (strong administrative stand against misconduct alters behavior of officers); Reiss, Controlling Police Use of Deadly Force, 452 Annals AM. ACAD. Pol. \& Soc. ScI. 122, 131, 142-44 (1980) (actions of supervisory personnel can reduce police violence).

54. See Whitman, supra note 9 , at 249-54 (institutions create injurious consequences through their very structures).

55. See Chapman, supra note 52, at 234 (administrators' failures may result from inadvertent neglect or conscious avoidance); Fyfe, Observations on Police Deadly Force, in REadings on Police USE OF DEADLY FORCE, supra note 52, at 297, 307-08 (failure to formulate policy usually unconscious); Rittenmeyer, supra note 52, at 265 (omissions usually basis of supervisory torts). Departments may institute practices in an attempt to achieve conflicting goals and may thus fail in their mandate to address unconstitutional behavior. See, e.g., Manning, Violence and the Police Rule, 452 ANNals AM. ACAD. Pol. \& Soc. ScI. 135, 141 (1980) (rather than rational response to pattern of violations, police disciplinary rules tend to be reflection of organizational need to avoid embarrassment).

56. In City of Los Angeles v. Lyons, 461 U.S. 95 (1982), that failure precluded even an accurate characterization of the policy alleged. Id. at 120-22 (Marshall, J., dissenting).

57. Justice O'Connor dismissed the possibility that a jury could reasonably find that the city's omissions caused the harm:

To conclude, in a particular instance, that omissions in a municipal training program constituted the "moving force" in bringing about the officer's unconstitutional conduct . . . appears to be largely a matter of speculation and conjecture. . . . [A] jury should be permitted to find that the municipality's inadequate training "caused" the plaintiff's injury only if the inadequacy of the training amounts to deliberate indifference or reckless disregard for the consequences.

Kibbe, 107 S. Ct. at 1120-21 (O'Connor, J., dissenting). 
prehending suspects fleeing in their cars and little training in applying regulations on the use of firearms. The court of appeals determined that, based on this and other evidence, the jury might have found that training in methods other than the use of deadly force would have prevented the death of Clinton Thurston and that the city was at fault for sending the officers to apprehend the suspect without the necessary preparation. ${ }^{88}$

If a plaintiff can prove that her injuries resulted from institutional inertia or neglect, she will satisfy the Monell causation requirement without any showing of municipal intent. ${ }^{69}$ The appropriate inquiry in assessing municipal liability is not whether policymakers intended or envisioned harm but whether their failure to act led the offending officer to violate a citizen's rights. ${ }^{80}$

58. Kibbe v. City of Springfield, 777 F.2d 801, 805-08 (1st Cir. 1985), cert. granted, 475 U.S. 1064 (1986), cert. dismissed, 107 S. Ct. 1114 (1987). Similarly, despite the Tuttle plurality's preference for "conscious choices," the expert testimony Tuttle offered on the nature and potential implications of the offending officer's training could have sufficed to establish causation. City of Oklahoma City v. Tuttle, 471 U.S. 808, 826, 830-33 (1985) (Brennan, J., concurring).

59. See Tuttle, 471 U.S. at 833 n.8 (1985) (Brennan, J., concurring) (if municipality takes actions, whether of type alleged in Monell or in Tuttle, that cause deprivation of citizen's rights, $\S 1983$ is available as remedy).

The Supreme Court has noted in the past that municipal institutions can cause harm inadvertently. When it denied municipal corporations a qualified, "good faith" immunity in Owen v. City of Independence, 445 U.S. 622 (1980), the Court remarked that "systemic" injuries can result even when policymakers act with good intentions, and that the compensation and deterrence functions of $\$ 1983$ would not be properly served if cities escaped liability for unintentional injuries:

Moreover, section 1983 was intended not only to provide compensation to the victims of past abuses, but to serve as a deterrent against future constitutional deprivations, as well. . . .

Furthermore, the threat that damages might be levied against the city may encourage those in a policymaking position to institute internal rules and programs designed to minimize the likelihood of unintentional infringements on constitutional rights. Such procedures are particularly beneficial in preventing those "systemic" injuries that result not so much from the conduct of any single individual, but from the interactive behavior of several government officials, each of whom may be acting in good faith.

Id. at 651-52 (footnotes omitted).

The Court has also indicated that a search for "malicious intent" is not appropriate where municipalities are concerned. See City of Newport v. Fact Concerts, Inc., 453 U.S. 247, 267 (1981) (in denying availability of punitive damages against city under $\$ 1983$, Court noted that because government entity cannot act with malice such damages are not sensibly assessed against it).

60 . The recent refusal by members of the Court to recognize the harm caused by unintended omissions has been made evident in the due process context as well. In Daniels v. Williams, 474 U.S. 327 (1986), and Davidson v. Cannon, 474 U.S. 344 (1986), plaintiffs alleged due process violations when prison officials failed to safeguard their property and liberty. Daniels injured himself by tripping on a pillow left on the jail stairs by a sheriff; Davidson, however, was assaulted by another inmate after a guard ignored his written plea for protection.

The Court maintained that neither prisoner's civil rights had been violated and distinguished these cases from those in which government officials make a deliberate decision to deprive a person of life, liberty, or property. Daniels, 474 U.S. at 331, 333-34. The majority contended that the federal courts should not be entertaining law suits in which there has been "no affirmative abuse of power." Id. at 330 (quoting Parratt v. Taylor, 451 U.S. 527, 548-49 (1981) (Powell, J., concurring in the judgment)).

But in his dissent in Davidson, Justice Blackmun argued that whether the prison guards intended to harm Davidson was immaterial to his cause of action. The guards neglected his plea for protection despite the substantial risk of harm; according to the dissent, such a failure to act constituted an abuse of power within the meaning of the due process clause. Davidson, 474 U.S. at 354-56 (Blackmun, J., dissenting).

Justice Blackmun's opinion makes clear that the relevant inquiry for omission is not always "intent 


\section{B. Intent Requirement Undermines Legislative Purpose of Section 1983}

The emerging limitations on the inaction theory not only restrict $\mathrm{Mo}$ nell unnecessarily but also vitiate the legislative intent underlying 42 U.S.G. $\S 1983$. Originally enacted as section 1 of the Civil Rights Act of 1871 , section 1983 was created to give citizens a remedy where their local government failed to protect their rights. The Reconstruction Congress was specifically concerned with the refusal of local officials to act when the Ku Klux Klan terrorized blacks. Congress deemed the provision necessary precisely because the police would not enforce the law: The recorded history of the Act is replete with descriptions of violent and brutal conduct left unpunished by helpless or complicit authorities. ${ }^{61}$

The legislative debates offer no hint that the authors of the provision wished to reach only the actions-as opposed to the omissions-of local authorities. On the contrary, members of Congress repeatedly expressed concern that the federal remedy not be limited to "lawless acts ... done in pursuance of any law or act,"62 but that it provide redress where municipalities "quietly permitted" "powerless" Forty-second Congress noted the futility of limiting the provision's coverage to overt deeds:

It is said that the States are not doing the objectionable acts. This argument is more specious than real. . . . What practical security would this provision give if it could do no more than to abrogate and nullify the overt acts and legislation of a State? If a State . . nevertheless permits the rights of citizens to be systematically trampled upon ... of what avail is the Constitution to the citizen? ${ }^{66}$

Nor is there any indication that the statute was meant to cover only intentional deprivations of rights. The Act was passed not because government actors necessarily meant to harm blacks but because they were una-

\footnotetext{
versus negligence" but whether the institution took an unacceptable risk in failing to act: "In some cases, by any reasonable standard, governmental negligence is an abuse of power. ... In some circumstances the risk of injury is so high that the government's failure to make efforts to avoid the injury is unacceptable, even if its omission still might be categarized as negligence." Id. at 353 \& n.2 (citations omitted; emphasis added) (Blackmun, J., dissenting).

61. See, e.g., Cong. Globe, 42d Cong., 1st Sess. 155 (1871) (remarks of Sen. Sherman) (black preacher found lynched; no one arrested or tried); $i d$. (warrant issued after men were severely beaten but investigation cut off after mobs threatened violence); id. at 158 (remarks of Sen. Sherman) (in the face of uncontroverted evidence, grand juries refused to indict; prosecutors hounded out of town).

62. Cong. Globe, 42d Cong., 1st Sess. 375 (1875) (remarks of Rep. Lowe).

63. Id.

64. Id. at 322 (remarks of Rep. Stoughton).

65. Id. at 653 (remarks of Sen. Osborn).

66. Id. at 375 (remarks of Rep. Lowe); see also Blackmun, supra note 44, at 16 ( 1983 was meant to reach activity of persons who did not necessarily have formal authorization of state); Monroe v. Pape, 365 U.S. 167, 174 (1961) (failure of states to enforce laws furnished momentum behind bill).
} 
ble or afraid, regardless of their intentions, to take action on these citizens' behalf. ${ }^{67}$ In fact, some legislators in the Forty-second Congress opposed the bill precisely because it would impose liability without regard to "willfulness."

The Forty-second Congress was concerned not with whether local authorities contemplated the consequences of their inaction but with whether a federal remedy was appropriate where municipal neglect caused harm. ${ }^{68}$ A court-imposed intent requirement would severely hinder the victim of police misconduct from obtaining redress under section $1983 .{ }^{70}$ The ultimate effect of the trend toward authorization would thus be to jeopardize

67. See. e.g., Cong. Globe, 42d Cong., 1st Sess. 158 (1871) (remarks of Sen. Sherman) ("I suppose any candid man in North Carolina would tell you it is impossible for the civil authorities, however vigilant they may be, to punish those who perpetrate these outrages."); see also id. at 155 (describing thwarted attempts by officials to prosecute lawbreakers).

68. See, e.g., id. at 365-66 (remarks of Rep. Arthur) (bill should be defeated because unlike earlier statutes it creates liability without regard to willfulness).

The Supreme Court has rejected "willfulness" as a requisite element of a $\$ 1983$ cause of action. See supra note 45 and accompanying text; see also Monroe v. Pape, 365 U.S. 167, 180 (1961) (statute passed to safeguard rights deprived "by reason of prejudice, passion, neglect, intolerance or otherwise"). Monroe specifically distinguished 42 U.S.C. $\$ 1983$ from its criminal counterpart, 18 U.S.C. $\S$ 242 , which provides a federal remedy for criminal behavior:

[In Screws v. United States, 325 U.S. 91 (1945),] we dealt with a statute that imposed criminal penalties for acts "wilfully" done. We construed that word in its setting to mean the doing of an act with "a specific intent to deprive a person of a federal right." We do not think that gloss should be put on [\$1983]... The word "wilfully" does not appear in [\$1983]. . . [Section 1983] should be read against the background of tort liability that makes a man responsible for the natural consequences of his actions.

Id. at 187 (citations omitted) (emphasis added).

69. See, e.g., Cong. GLobe, 42d Cong., 1st Sess. 448 (1871) (remarks of Rep. Butler) (state has no constitutional or other right to deny or neglect to provide equal protection of the law); see also Schnapper, supra note 9, at 242 (whether failure to secure protection of the laws was willful or the result of inability made no difference; debates focused not on states' desire to violate equal protection clause but on "indifference" and "neglect").

70. Evidence on how a department came to choose a training program or disciplinary procedure would be in the hands of the defendant police officials themselves. Even if a plaintiff could obtain such information, she would still face the nearly insurmountable task of establishing that an official knew that misconduct would "inevitably" result from the program or deliberately ignored prior instances of abuse.

As the Kibbe dissent noted, claims such as the plaintiff's that would prevail under a negligence or gross negligence standard would face dismissal where proof of deliberate indifference were required. City of Springfield v. Kibbe, 107 S. Ct. 1114, 1121 (1987) (O'Connor, J., dissenting). Courts that have adopted the "inevitability" or deliberate indifference standard have repeatedly granted defendants' motions to dismiss on the ground that plaintiffs could not provide evidence sufficient to meet the intentionality demand. See, e.g., Carter v. District of Columbia, 795 F.2d 116 (D.C. Cir. 1986); Patzner v. Burkett, 779 F.2d 1363 (8th Gir. 1985); Fecteau v. Unknown Officers of Clinton, 596 F. Supp. 580 (E.D. Mich. 1984). 
municipal relief ${ }^{71}$ for one class of plaintiffs for whom the provision was clearly designed. ${ }^{72}$

\section{An Alternative Judicial Approach}

The Supreme Court has undermined both Monell and section 1983 itself by threatening to require proof of intent or authorization before municipal liability will attach. This trend should be rejected in favor of an approach that neither amounts to respondeat superior liability nor impermissibly burdens the civil rights plaintiff. By using an objective standard for evaluating program adequacy and a causation test consonant with the policies justifying municipal liability under section 1983, courts can achieve this result.

Where official conduct is at issue, the risk of injury may in some instances be so unacceptably high that failure to take action constitutes an abuse of power. ${ }^{73}$ Deficient preparatory or supervisory safeguards may create just such a risk in a law enforcement setting, regardless of whether they were chosen or maintained through deliberation or inertia. ${ }^{\mathbf{7}}$

71. Sometimes, of course, plaintiffs will be able to succeed under the more restrictive standard by either offering evidence of actual knowledge or deliberation or presenting facts so egregious that a trial judge would deem the policymakers' behavior "deliberately indifferent" or "inevitably" resulting in future abuse. For example, in Herrera v. Valentine, 653 F.2d 1220 (8th Cir. 1981), a Native American woman sued the local government after police kicked her in the abdomen though she was visibly pregnant, threatened to shoot her, and then denied her medical care so that she lost her baby. Prior to the incident, hearings had been held on the abusive treatment of Native Americans by local law enforcement agents, but authorities did nothing to respond to the numerous complaints of brutality that were made. The court found here that the city's failure to act resulted in the "inevitability" of an incident such as plaintiff's and awarded her damages against the municipality. Id. at 1222-26; see also Rymer v. Davis, 754 F.2d 198 (6th Cir.), vacated and remanded sub nom. City of Shepherdsville v. Rymer, 473 U.S. 901, affd sub nom. Rymer v. Davis, 775 F.2d 756 (6th Cir. 1985) (suspect beaten, kicked, jailed, and deprived of medical care; circuit court, on remand after Tuttle, found city's omissions met inevitability standard).

Yet limiting redress to only isolated, flagrant constitutional violations would allow a city to escape liability in numerous cases in which it is at fault. As the Court remarked in Owen v. City of Independence, 445 U.S. 622, 651 (1981), it would be "uniquely amiss" if the government itself-as the protector of citizens' rights-were allowed to disavow liability for the injuries it generates. Indeed, acceptance of a proof-of-intent requirement where inaction is alleged would have the effect of granting municipalities a limited immunity, the outcome desired by the dissenters in Owen in 1980: Municipalities could be shielded by their good intentions and be found liable only for the most egregious constitutional violations. See id. at 666, 673-75, 679 (Powell, J., dissenting); see also City of St. Louis v. Praprotnik, No. 86-772 (U.S. Mar. 2, 1988) (LEXIS, Genfed library, U.S. file) (Brennan, J., concurring) (Congress did not enact $\$ 1983$ simply to reach only those deprivations that are truly "egregious.").

72. Indeed, many of the anecdotes related in $\$ 1983$ 's legislative history bear a compelling resemblance to the claims of brutality brought against police officials today. See, e.g., Blackmun, supra note 44, at 17-18 (quoting Shapo, Constitutional Tort: Monroe v. Pape, and the Frontiers Bejond, 60 Nw. U.L. REv. 277 (1965) (noting similarity between police misconduct alleged in Monroe and beatings described in floor debate in 1871)).

73. See Davidson v. Cannon, 474 U.S. 344, 353 n.2 (1986) (Blackmun, J., dissenting); see also Owen v. City of Independence, 445 U.S. 622 (1981).

74. See supra notes 52-55 and accompanying text; see also W. Prosser \& W. KeEton, supra note $14, \S 31$, at 170 ("Risk ... may ... be defined as a danger which is apparent, or should be apparent, to one in the position of the actor.") (emphasis added); Mead, supra note 34, at 556 (inadequate supervision creates tremendous potential for unconstitutional behavior; municipality cre- 
Whether such inadequacies caused harm in a particular case should therefore be determined not by an inquiry into a policymaker's state of mind but by objective criteria that juries are asked to evaluate. ${ }^{75}$

The threshold issue in police misconduct litigation is determining when training inadequacies or supervisory omissions can be considered "policy" within the meaning of Monell. ${ }^{76}$ To prove the existence of a policy, plaintiffs should not have to show that the municipality's choice of training program rendered brutality inevitable, or that a chief knew his or her responses to misconduct would result in further harm. Rather, victims of police abuse should have to prove that the department followed procedures or practices that a reasonable administrator would have known would lead to misconduct. ${ }^{77}$

In seeking to establish "policy," a plaintiff would first identify the departmental program or practice allegedly responsible for the violation. ${ }^{78}$ The litigant would next show, perhaps through expert testimony or data on customary police practice, that the procedure is inadequate (i.e., that it creates a risk of harm of which a reasonable police administrator would have been aware) ${ }^{79}$ The municipal defendant would then have the oppor-

ating such a risk should bear cost when risk becomes reality).

75. See W. Prosser \& W. KeEton, supra note 14, §32, at 173-74 (standard of conduct, to be applied by jury, must be external and objective, rather than based on individual judgment of particular actor).

76. The state-of-mind analysis conflates the two distinct strands of the Monell test: policy and causation. See Comment, City of Oklahoma City v. Tuttle: Causation in Municipal Liability Cases Under Section 1983, 11 OKLA. CrTY U.L. REv. 207, 212 (1986); see also supra notes 33-34 and accompanying text.

77. The critical difference between this test and that sought by the Kibbe dissent and Tuttle plurality is that it relies on objective rather than subjective foresight. Instead of examining the policymaker's actual state of mind, this approach presumes law enforcement authorities to be informed, within reason, of the dangers of poor police practices and programs.

The Supreme Court implicitly recognized this distinction when it affirmed a judgment against the city of Memphis in Brandon v. Holt, 469 U.S. 464 (1985). The suit involved an unprovoked stabbing and shooting by an officer with a history of violence. The trial court held the department director liable although he had no actual knowledge of the officer's dangerous propensities on the theory that he should have known of them and was only shielded by deficient procedures. While the questions before the Court concerned amendment of pleadings and official immunity, Justice Stevens' opinion quoted at length from the district court's finding that the police administrator could not be absolved of liability because he was insulated by departmental policies from knowledge of wrongdoing. Id. at 467 \& n.6.

Other commentators have understood "policy" under Monell to include municipal conduct that would foreseeably cause constitutional injury. See Friedman, Parratt v. Taylor: Opening and Closing the Door on Section 1983, 9 HASTINGs CONST. L.Q. 545, 567 (1982) (§ 1983 applicable where negligent acts create foreseeable risk to constitutional rights); Schnapper, supra note 9, at 234-35, 236 (policies entailing unreasonable risk of causing constitutional violation actionable); see also City of Oklahoma City v. Tuttle, 471 U.S. 808, 832 (1984) (Brennan, J., concurring) (§ 1983 available for victim of policy or custom that would foreseeably and avoidably cause individual to be subjected to deprivation of constitutional right).

78. These might include training in how and when to use a given weapon or tactic; restrictions on the use of deadly force; preparation for encounters with potentially hostile suspects; measures for coping with stressful or threatening situations; periodic inservice training for officers; follow up programs for new recruits; and procedures for handling complaints filed against officers.

79. See Berquist v. County of Cochise, 806 F.2d 1364 (9th Cir. 1986) (allegation that official reasonably should have known that failure to act would cause others to inflict constitutional injury stated claim); Anthony v. Baker, 767 F.2d 657 (10th Cir. 1985) (sheriff accountable if knew or reasonably should have known of misconduct yet failed to prevent future harm). 
tunity to challenge plaintiff's claims with its own evidence. To determine whether the plaintiff has proved an actionable policy, jurors might consider the duration and intensity of a training program, the clarity of municipal guidelines on the use of force, or the manner of implementation of disciplinary procedures. ${ }^{80}$ If the jury finds that the program or posture violates a reasonable standard of care, the plaintiff will have satisfied the initial inquiry of the Monell test. ${ }^{81}$

The litigant who establishes "policy" under these criteria would then have to prove that this policy caused her injury. To establish the link between the municipal conduct and the harm, plaintiffs would not have to show that municipal authorities deliberately ignored incidents of brutality or "knew" that constitutional violations would result when they chose a training program. The misconduct victim would instead prove that the city's policy was a substantial factor ${ }^{82}$ in the causation of the tort. To that end, a plaintiff might offer testimony from police experts showing that the department's failure to discipline its officers was a substantial cause of the beating she received or that proper training would have prevented unnecessary use of a firearm. In its defense, the city might argue that even adequate preparation could not have anticipated the behavior of the defendant officer in this case. ${ }^{83}$ The jury would then determine whether the

80. A plaintiff must be given the chance to conduct adequate discovery to establish her claim. Critical information often will be in the hands of the opposing party, and the litigant's action should not be dismissed before she has obtained access to the relevant data on training or the incidence of brutality. See Owens v. Haas, 601 F.2d 1242, 1247 (2d Cir.), cert. denied sub nom. County of Nassau v. Owens, 444 U.S. 980 (1979).

81. Some might argue that this approach imposes an impermissible "affirmative duty" on local governments to institute specific procedures to avoid liability or to take other affirmative action. A reasonable foreseeability standard, however, does not require any action on the part of the municipality other than the exercise of due care under the circumstances. See W. Prosser \& W. KeEton, supra note 14, § 34, at 209; Owen v. City of Independence, 445 U.S. 622, 656 (1980) (officials must consider whether their policies comport with constitutional mandates).

82. The "substantial factor" analysis is useful when more than one cause has contributed to an event. W. Prosser \& W. KeEton, supra note $14, \$ 41$, at $267-68$. In the police misconduct context, both the individual officer's act and, if proved, the improper guidance he received might be considered causes of the plaintiff's injury. This test acknowledges that the city is not the sole actor and holds it accountable only where it can be shown to be largely responsible. This approach is also consistent with the deterrence objectives of $\S 1983$ in that it refuses to absolve the city from liability merely because its conduct is not the unique cause of the harm. See Eaton, Causation in Constitutional Torts, 67 IowA L. REv. 443, 455-56 (1982) (substantial factor standard predicated on conviction that wrongdoer should not be permitted to avoid consequences of wrongful conduct; provides incentive for deterrence).

Even Justice O'Connor's dissent in City of Springfield v. Kibbe, 107 S. Ct. 1114 (1987), expressed approval of the "substantial factor" test in determining causation. Id. at 1121 (O'Connor, J., dissenting). Contrary to the dissent's assertion, however, a plaintiff could prove that the city's policy was a substantial cause of the harm by, for example, relying on the testimony of experts in the field.

83. This method of handling claims would not lead to an assumption of municipal responsibility whenever a patrolling officer committed a constitutional tort. City authorities could not be held accountable where officers flouted sound procedures or committed unforeseeable violations. Furthermore, plaintiffs face a significant burden in proving that departmental procedures were a substantial cause of their injuries.

Nor could this standard be said to lead to "overdeterrence" of the policing function: A department that can show, despite plaintiff's evidence, that a particular policy is necessary to vigorous enforcement 
departmental "policy" was a legal cause of the constitutional violation. ${ }^{84} \mathrm{~A}$ finding of causation would result in a determination of liability against the municipality. The city would thus be held accountable only where its own failure to train or discipline its police force was shown to have caused harm.

This approach is consistent with Monell and the legislative purpose of section 1983. It affirms the principle that municipalities must avoid complicity in the illegal acts of law enforcement agents. Deterrence of governmental abuse-a motivating force behind the passage of the civil rights statute-will be encouraged if municipal officials are held liable where their conduct is a substantial factor in creating harm. Courts will be relieved of having to grope for an acceptable standard in seeking to avoid respondeat superior liability. By relying on a reasonable foreseeability test and considering causation separately under a "substantial factor" analysis, courts can evaluate claims of a city's failure to train or discipline adequately within the test established by Monell.

\section{GonClusion}

The judicial trend toward requiring proof of municipal intent or affirmative authorization in section 1983 cases must be rejected. By demanding intent, the courts restrict a cause of action based on municipal omissions, thus undermining both the viability of Monell and the legislative purpose of the civil rights statute. An intent requirement would preclude recovery for most victims of police brutality who allege municipal responsibility for their injuries, thereby reducing deterrence and incentives for institutional improvement. Rather than require affirmative authorization or intent, courts should employ a standard of reasonable foreseeability of harm in assessing municipal responsibility. If a municipal policy of neglect has allowed a citizen to be abused by the police, the victim will then be able to seek the relief that section 1983 was enacted to provide.

of the law will have established its reasonableness. See Tennessee v. Garner, 471 U.S. 1, 9-11 (1984) (in determining reasonableness of fleeing felon law, Court weighed state's interest in effective law enforcement against potential harm to citizens' rights).

84. See Rittenmeyer, supra note 52, at 263 (showing that deprivation resulted from natural and foreseeable consequence of supervisory inaction establishes causal link); see also Eaton, supra note 82, at 479-80. Plaintiffs often rely on expert testimony to establish the causal link between the city's failures and the officer's conduct. See, e.g., City of Oklahoma City v. Tuttle, 471 U.S. 808, 830-33 (1985) (Brennan, J., concurring). Police experts may show that an officer's training left her illequipped to master a dangerous situation and therefore constituted the "moving force" of the injury to the plaintiff. If a jury finds the expert's evidence credible, plaintiff will have established the very causal connection that the Kibbe dissenters consider "tenuous." See supra notes 22-24 and accompanying text. 